\title{
Differences in the Mechanism of In Vitro Immune Hemolysis Related to Antibody Specificity *
}

\author{
David A. Sears, $\dagger$ Robert I. Weed, $\ddagger$ and Scott N. Swisher $§$ with the tech- \\ NiCal assistance of Norma Trabold \\ (From the Departments of Medicine and Radiation Biology, University of Rochester School \\ of Medicine and Dentistry, Rochester, N. Y.)
}

This investigation of the mechanism of immune hemolysis was undertaken to define qualitatively and quantitatively the processes involved in the breakdown of the human red cell membrane produced by the action of complement $\left(\mathrm{C}^{\prime}\right)$ and hemolytic antibodies of differing specificity.

Recent investigations in man and animals have provided insight into patterns of immune hemolysis occurring in the intact organism (1-4). At the cellular level, the kinetics of antibody dependent hemolysis and of $\mathrm{C}^{\prime}$ action have been studied extensively by many investigators, utilizing the classical sheep erythrocyte-rabbit antibody-guinea pig $C^{\prime}$ system (5). Ponder (6) has described the kinetics of hemolysis produced by a wide variety of chemical and physical agents. Little is known, however, about the nature of the injury to the human red cell membrane induced by antibody and $\mathrm{C}^{\prime}$ and the mechanism by which that injury ultimately leads to hemolysis.

Although the normal intact red blood cell is isotonic with its plasma environment, as recently demonstrated by Williams, Fordham, Hollander, and Welt (7), this is possible only because of an effective or net impermeability to cations that,

* Submitted for publication November 18, 1963; accepted January 15, 1964.

Supported in part by the U. S. Atomic Energy Commission at the University of Rochester Atomic Energy Project, Rochester, N. Y.

Presented in part at the 55th Annual Meeting, The American Society for Clinical Investigation, Atlantic City, N. J., April 28, 1963.

† Trainee under training grant 5-TI-AM 5113-08 NIAMD, National Institutes of Health. Present address : Walter Reed Army Institute of Research, Washington, D. C.

$\ddagger$ Recipient of U. S. Public Health Service research grant HE-06241-02.

§ Recipient of research grant AM-00537-15 from the National Institute of Arthritis and Metabolic Diseases. to preserve electrical neutrality, permit no net passage of electrolytes, but anions, hydrogen, and hydroxyl ions can rearrange themselves. However, the disruption of this normal cation impermeability permitting free diffusion of cations across the membrane, because of the Donnan effect, leads to cell swelling and eventual cell lysis, i.e., escape of hemoglobin. This mechanism of hemolysis was described in 1936 by Davson (8) and was termed colloid-osmotic hemolysis by Wilbrandt in 1941 (9). Recently, Dick has summarized the topic clearly (10). An analogous system has been demonstrated by Goldberg, Green, Barrow, and Fleischer (11-13) in their studies of the lysis of Krebs ascites tumor cells by rabbit antibody and $C^{\prime}$. The cells exposed to antibody and $\mathrm{C}^{\prime}$ rapidly became permeable to cations and other small molecules. Cell swelling and escape of larger molecules such as RNA were prevented by increasing the osmotic pressure of the external medium with added albumin. Since sucrose did not prevent cell swelling or loss of the large molecules of the cell, these authors concluded that antibody and $\mathrm{C}^{\prime}$ had created functional "holes" in the cell membrane of a size between that of sucrose and albumin and that osmotic swelling was necessary to permit the egress of large molecules from the damaged cells. Based on these observations and the finding of a similar mechanism in antibody- $\mathrm{C}^{\prime}$ lysis of mouse erythrocytes, Green and Goldberg (14) have suggested that colloid osmotic lysis is a general mechanism by which animal cells injured by antibodies and $\mathrm{C}^{\prime}$ are lysed.

Our investigation was designed to study antibody- $\mathrm{C}^{\prime}$ hemolysis of human red cells in vitro utilizing methods similar to those employed by Green and associates (13) to determine if antibody- $\mathrm{C}^{\prime}$ hemolysis proceeded by a colloid-osmotic 
mechanism in this situation and to quantitate the size of induced membrane defects. If the action of antibody and $\mathrm{C}^{\prime}$ produces membrane defects too small to permit the direct egress of hemoglobin, cell swelling and hemolysis should be prevented by the addition to the medium of nonpenetrating and, therefore, osmotically active molecules in appropriate concentrations to balance the greater intracellular osmotic pressure. Since only molecules larger than the membrane defect remain outside the cell and thus prevent cell swelling and hemolysis, an estimate of the size of the membrane defect can be obtained by testing molecules of various known sizes in the medium. In the present study, we have investigated the effects of sucrose, bovine serum albumin, human hemoglobin, and dextran fractions of various molecular sizes on in vitro hemolysis of human red cells by three different antisera and $\mathrm{C}^{\prime}$.

\section{Methods and Materials}

Red blood cells. Blood was obtained from hematologically normal adult male and female donors of groups $\mathrm{A}, \mathrm{B}, \mathrm{AB}$, and $\mathrm{O}$; both $\mathrm{Rh}$-positive and -negative donors were included. A fraction of blood was mixed with approximately $1 \mathrm{U}$ of heparin per $\mathrm{ml}$ of blood, and the sample was centrifuged at $1,700 \times g$ for 10 minutes. The plasma and buffy coat were removed by aspiration and the red cells washed three times with 5 vol of $1 \%$ sodium chloride.

Complement. A second sample of the same blood from which red cells were obtained was allowed to clot for 1 hour at room temperature. The serum was removed and utilized as a source of $\mathrm{C}^{\prime}$.

Rabbit antihuman red cell serum. Blood was collected in standard acidified citrate dextrose from a type $\mathrm{O}$, $\mathrm{Rh}_{\mathrm{o}}+, \mathrm{NN}$ human donor. The red cells were separated and washed four times with 3 vol of $0.9 \%$ sodium chloride. One $\mathrm{ml}$ of packed red cells was injected intravenously into each of four 2 - to $3-\mathrm{kg}$ adult rabbits. Similar injections were repeated twice at 10-day intervals. Eight and 11 days after the third immunization, the rabbits were bled from ear veins, and serum was collected. The sera from the four rabbits were pooled and heated for 30 minutes at $56^{\circ} \mathrm{C}$, Seitz-filtered, and stored in the frozen state at $-20^{\circ} \mathrm{C}$. To ascertain the antibody titer of this serum, fresh, washed human red cells of groups $\mathrm{A}, \mathrm{B}, \mathrm{AB}$, and $\mathrm{O}$ were prepared as $3 \%$ suspensions in fresh autologous serum. Portions of these red cell suspensions were incubated for 1 hour at $37^{\circ} \mathrm{C}$ with saline dilutions of the pooled rabbit serum. Hemolysis and direct agglutination were then observed, and, in tubes beyond the agglutination end point, antiglobulin tests were performed on those tests involving human $\mathrm{A}+$ erythrocytes. A sheep anti-rabbit globulin serum, from which the heteroagglutinin for human red cells had been removed by repeated adsorption with groups $\mathrm{A}, \mathrm{B}$, and $\mathrm{O}$ cells at $4^{\circ} \mathrm{C}$ and at room temperature, was employed in a single dilution. The titers thus obtained for the rabbit antiserum against human group A cells (both $A_{1}$ and $A_{2}$ ) were as follows: hemolysis, $1: 100$; direct agglutination, $1: 4,000$; and positive antiglobulin test, $1: 16,000$. Similar agglutinin and hemolysin titers were observed with the other test erythrocytes.

Human anti- $A$ serum. Whole serum containing a high titer of human anti-A of "immune" character had been obtained from a group $O$ individual (15) previously and stored frozen at $-20^{\circ} \mathrm{C}$. The serum was filtered through a Millipore filter ${ }^{1}(0.2 \mathrm{~m} \mu$ pore size $)$ to remove a small amount of particulate matter. Titers of this serum against the group $A_{1}$ red cells employed in these experiments were as follows: hemolysis, 1:64; direct agglutination, $1: 2,048$. The titers against human $A_{2}$ cells were somewhat lower, and $A_{1}$ cells were used in all experiments with this antiserum.

Rabbit antihuman $A$ serum. ${ }^{2}$ The serum was heated at $56^{\circ} \mathrm{C}$ for 20 minutes and absorbed twice with guinea pig kidney to remove anti-Forssman antibody. The absorbed serum was titered against human group $A_{1}$ red cells with the following results: hemolysis, $1: 40$; direct agglutination, $1: 5,120$.

Fractionation of antisera. One-ml samples of the rabbit antihuman red cell serum and the human anti-A were dialyzed against $0.02 \mathrm{M}$ phosphate buffer $(\mathrm{pH} 6.31)$ at $4^{\circ}$ $\mathrm{C}$ for 24 hours. The dialysates were applied to small diethylaminoethanol (DEAE) cellulose columns to separate $7 \mathrm{~S}, \gamma_{2}$ from $19 \mathrm{~S}, \gamma_{1 \mathrm{M}}$ globulins as described by Kochwa, Rosenfield, Tallal, and Wasserman (17). The $7 \mathrm{~S}$ globulins were eluted from the column with the 0.02 $\mathrm{M}$ phosphate buffer and the $19 \mathrm{~S}$ with $1 \mathrm{M}$ sodium chloride, both at a flow rate of 1 drop per 20 seconds.

To concentrate the activity of the antibody, the $7 \mathrm{~S}$ fractions were mixed with an equal volume of saturated ammonium sulfate solution. The precipitate was allowed to develop for 30 minutes at room temperature and was then removed by centrifugation and redissolved in a small volume of water. The resulting solution was dialyzed for 24 hours against $0.9 \%$ sodium chloride at $4^{\circ} \mathrm{C}$. Isotonic solutions of the $7 \mathrm{~S}$ fraction of human anti-A were thus obtained with titers of hemolytic activity against human group $A_{1}$ red cells only slightly less than those of the whole serum. The fractions eluted from the column with $1 \mathrm{M}$ sodium chloride exhibited primarily agglutinating activity and no demonstrable hemolytic activity against human group $\mathrm{A}_{1}$ cells.

Hemoglobin solution. Human red cells were washed three times with $1 \%$ sodium chloride and hemolyzed with 3 vol of distilled water. After centrifugation of 12,000 $\times g$ for 45 minutes, the clear supernatant hemoglobin

${ }^{1}$ Millipore Filter Corp., Bedford, Mass.

2 Kindly provided by Dr. Harold Baer, Division of Biologics Standards, National Institutes of Health [described by him as "pool 1" (16)]. 
solution was removed and dialyzed against hypotonic sodium chloride solution at $4^{\circ} \mathrm{C}$ for 32 hours. After concentration by pervaporation, a final solution of $3.7 \mathrm{mM}$ hemoglobin in isotonic sodium chloride was obtained that contained only $1 \mathrm{mEq}$ per $\mathrm{L}$ of potassium ion.

Albumin. Commercial bovine serum albumin (Fraction V) ${ }^{3}$ was used; the generally accepted molecular weight of 69,000 was assumed.

Dextrans. Well-characterized dextran fractions of different molecular weights were utilized. ${ }^{4}$ Number average molecular weights of the polydisperse dextran fractions were used for calculations of dextran osmolarity, since these measurements best reflect their colligative properties, as described by Billmeyer (18).

Preparation of samples and incubation. When albumin and sucrose were used to increase the osmotic pressure of the medium, these substances were dissolved directly in the fresh serum at the desired concentrations. The dextrans could not be dissolved in unheated serum in sufficient concentration. These were added to serum as concentrated solutions dissolved in $0.1 \mathrm{M}$ Tris buffer $(\mathrm{pH}$ 6.4) adjusted to isotonicity with sodium chloride. Warming of the dextran and buffer in a water bath expedited solution. In the experiment utilizing hemoglobin in the medium, the above described hemoglobin solution in isotonic sodium chloride was added to serum. In all experiments, the $\mathrm{pH}$ of the suspending medium was adjusted to 7.0 to 7.2 with $\mathrm{HCl}$ before incubation. The desired volume of red blood cells then was added to the suspending medium. Finally the antiserum was added. The relative proportions of antiserum, fresh serum, and red blood cells were kept constant in each experiment, and appropriate control samples lacking antiserum or containing $\mathrm{C}^{\prime}$ inactivated by heat $\left(56^{\circ} \mathrm{C}\right.$ for 30 minutes) were included in each protocol. The total volume of test samples varied in different experiments from 2.0 to $4.4 \mathrm{ml}$ and the hematocrits of incubation mixtures from 2.3 to 10 vol per $100 \mathrm{ml}$. Samples were incubated under air in siliconized flasks for 2 hours at $37^{\circ} \mathrm{C}$ in a Dubnoff metabolic shaker. In all experiments the percentage of hemoglobin and potassium lost from the red cells was quantitated after incubation.

Determination of hemoglobin lost from incubated red cells. Hemoglobin determinations by the cyanmethemoglobin method of Crosby, Munn, and Furth (19) were carried out on the whole sample and the supernatant medium after incubation. Hematocrits were determined by the microhematocrit method. The percentage of hemoglobin loss from the erythrocytes was then calculated by the following formula: OD supernatant medium $\times(100$ - hematocrit)/OD whole sample $\times$ dilution factor. Even in experiments in which no protective macromolecules were added to the medium, the percentage of loss of hemoglobin from the cells in each sample was somewhat less than the percentage of loss of potassium. This differ-

${ }^{3}$ Obtained from Squibb and Co., New York, N. Y

4 Obtained from Pharmacia Fine Chemicals, Inc., Uppsala, Sweden, and Rochester, Minn. ence was accounted for by the retention of some hemoglobin by the lysed red cells. Hemoglobin retention by red cell ghosts is well recognized and has been described by Ponder (20) and Passow and Tillman (21). In the present experiments, determinations of the hemoglobin content of ghosts resulting from the lysis of red cells by the rabbit antihuman red cell antiserum confirmed the retention of hemoglobin by lysed cells. In the absence of protective additives in the medium, this difference between potassium and hemoglobin loss was generally less than $10 \%$.

In one series of experiments in which hemoglobin itself was added to the medium as a protective macromolecule, the percentage of loss of hemoglobin from the red cells was determined in a different manner. The test red cells were incubated for 90 minutes at room temperature with sodium chromate- $\mathrm{Cr}^{31}$ and were then washed three times with $1 \%$ sodium chloride. The radioactivities of the red cells thus labeled and of the supernatant fluid of each sample after incubation were compared in a well-type scintillation counter. The percentage of the red cell radioactivity appearing in the supernatant liquid after incubation permitted estimation of the percentage of hemoglobin lost from the cells. Preliminary studies had established that $\mathrm{Cr}^{51}$, which becomes tightly bound to intracellular hemoglobin, is not released to competitive binding by hemoglobin added to the medium.

Potassium determinations. Potassium was determined in samples and standard solutions by flame photometry ${ }^{5}$ utilizing an internal lithium standard. The percentage of red cell potassium lost to the medium during incubation was calculated from the potassium content of the red cells before incubation, that of the supernatant fluid before and after incubation, and that of the sample volume and the hematocrit after incubation.

In some experiments, the osmotic fragility of the unhemolyzed red cells was determined after incubation by the method of Parpart and colleagues (22). Red cells and red cell ghosts were quantitated by counting with a Coulter model A electronic particle counter. ${ }^{6}$ Ultrafiltration was performed according to the method of Toribara (23).

Osmotic pressure measurements. The concentration, and hence osmotic pressure, of hemoglobin in the cell is much greater than the concentration of protein in serum. In these experiments the addition of macromolecules to the medium was designed to balance this greater osmotic pressure and thus to prevent cell swelling. The concentrations of albumin and other macromolecules used were selected both on the basis of published data on the osmolarity of hemoglobin and the osmolarity of serum albumin, as well as on the results of some direct measurements of osmolarity. Osmotic pressure measurements on concentrated albumin solutions have been reported by

${ }^{5}$ Baird-Atomic flame photometer, Baird Atomic, Inc., Cambridge, Mass.

${ }^{6}$ Coulter Electronics, Hialeah, Fla. 
Scatchard, Batchelder, and Brown (24) and on concentrated hemoglobin solutions by Adair (25). Comparison of these data indicates that the concentrations of albumin used in these experiments were adequate to balance the osmotic pressure exerted by the intracellular hemoglobin.

Total osmolarity measurements were performed with a vapor pressure osmometer ${ }^{7}$ standardized with sodium chloride solutions. When the osmotic pressure of normal human serum was compared with that of serum to which $2.6 \mathrm{mM}$ albumin had been added, an increase of 38 mOsm per $\mathrm{L}$ was observed. However, ultrafiltration of a solution of the bovine serum albumin in deionized water and subsequent osmotic pressure measurements on the ultrafiltrate demonstrated that such solutions contained $20 \mathrm{mOsm}$ per $\mathrm{L}$ of ultrafiltrable nonprotein material of which approximately $10 \%$ was found to be sodium chloride. Since the ultrafiltrable material could be expected to cross altered, cation-permeable red cell membranes, however, the effective increment in osmotic pressure due to added macromolecules in a $2.6 \mathrm{mM}$ solution of this albumin in serum was $18 \mathrm{mOsm}$ per L. This figure is in good agreement with that of Scatchard and co-workers (24) and is comparable to the osmotic pressure of intracellular hemoglobin as discussed by Adair (25). Since the ultrafiltrable material would not be expected to offer protection, it was not removed. Although adequate centrifugation of cells from $2.6 \mathrm{mM}$ added albumin is not possible, measurement of the volume of normal cells in $2.0 \mathrm{mM}$ added albumin reveals no significant change in cell volume.

The osmotic coefficient of dextran, like that of albumin and hemoglobin, has been shown by Rowe (26) and Grönwall and Ingelman (27) to rise disproportionately with increasing concentration in solution. Osmotic pressure measurements on a $3.2 \mathrm{mM}$ solution of Dextran 40 in normal serum showed an increase in osmotic pressure of $14 \mathrm{mOsm}$ per L over serum without dextran.

\section{Results}

Studies utilizing rabbit antihuman red cell serum. Preliminary experiments showed that when group $A_{1}$ human red cells were incubated with rabbit antihuman red cell serum and fresh autologous serum as a source of $\mathrm{C}^{\prime}$, the rate of hemolysis increased with increasing amounts of antiserum per volume of red cells. The percentage of red cell potassium lost during incubation paralleled the percentage of hemoglobin lost. After studies of the time course of hemolysis by this system, 2-hour incubations were chosen since we had found that at that time the rate of hemolysis was nearly constant. Red cells incubated without antiserum showed negligible loss of red cell potassium and hemoglobin in 2-hour incuba-

\footnotetext{
${ }^{7}$ Mechrolab Inc., Mountain View, Calif.
}

tions. Similarly, the red cells in samples containing heat-inactivated $\mathrm{C}^{\prime}$, in spite of marked erythrocyte agglutination after incubation, lost only a minimal proportion of their potassium or hemoglobin, generally well less than $10 \%$.

The addition of albumin to the medium brought about a marked change in the pattern of loss of cellular contents (Figure 1). Potassium loss from the red cells was unaltered, but hemoglobin loss was greatly inhibited. With $3.9 \mathrm{mM}$ albumin added to the medium, ${ }^{8} 72 \%$ of the red cell potassium was lost but only $5 \%$ of the hemoglobin. Antibody and $\mathrm{C}^{\prime}$ had altered the cation permeability of the cell membrane to allow potassium escape. Hemolysis had been prevented because of the osmotic effect of the added albumin, which balanced the osmotic pressure of the macromolecules in the cell and prevented cell swelling.

To substantiate this interpretation further, we determined the osmotic fragility of cells thus "protected" by albumin against hemolysis. During 2 hours of incubation only $19 \%$ of the hemoglobin escaped to the medium, whereas $91 \%$ of the red cell potassium was lost. The osmotic fragility of these cells (Figure 2) showed that

8 The albumin concentrations refer to the amounts added to the medium and do not include the concentration of albumin, or other macromolecules, already present in the serum.

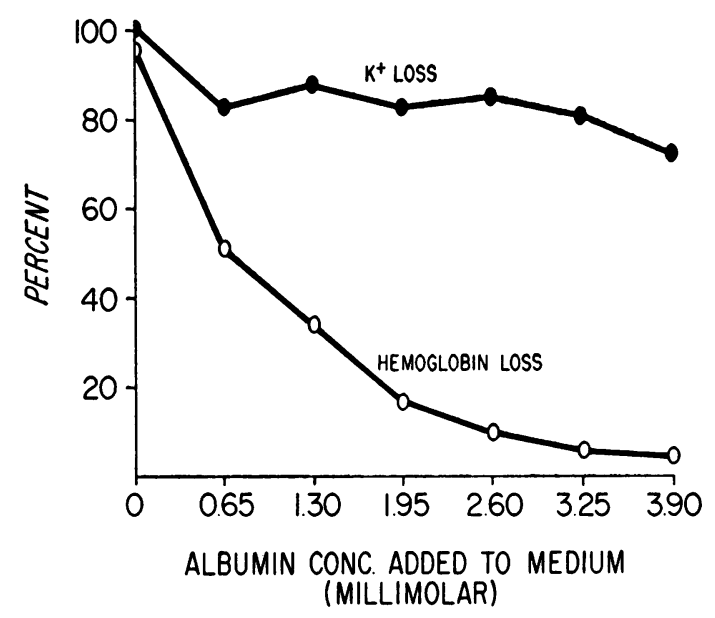

Fig. 1. The effect of albumin on loss of potasSIUM AND HEMOGLOBIN PRODUCED BY RABBIT ANTIHUMAN RED CELl ANTISERUM AND $C^{\prime}$. Each sample contained 0.2 $\mathrm{ml}$ red cells, $1.6 \mathrm{ml}$ fresh serum containing the added albumin, $0.1 \mathrm{ml}$ antiserum, and $0.1 \mathrm{ml} 1 \%$ sodium chloride. 
fiftyfold dilution of the medium with isotonic (1\%) saline resulted in lysis of $84 \%$ of the cells. Control samples incubated without antibody or with $C^{\prime}$ inactivated showed essentially normal osmotic fragility. Thus, the cells incubated with antibody in the presence of albumin clearly had become permeable to sodium as well as to potassium.

When Dextran 40 (weight average molecular weight, 35,700 ) was added to the medium, the results were similar to those obtained with albumin (Figure 3). Loss of potassium was unaffected, but loss of hemoglobin was almost totally inhibited by the higher concentrations of dextran. As in the experiments with albumin, dilution of the medium of the dextran-protected red cells with $1 \%$ saline for osmotic fragility determinations resulted in marked hemolysis; the extent of the hemolysis again agreed closely with the amount of potassium lost before dilution.

To define the lower limit of size of molecules that could protect against loss of hemoglobin, Dextran 10 (weight average molecular weight, 9,400 ), Dextran 20 (weight average molecular weight, 22,700), and sucrose (molecular weight, 342 ) were added to the medium in similar experiments. Figure 4 illustrates the results obtained utilizing Dextran 10. Obviously Dextran 10 provides no protection against loss of hemoglobin from the red cells injured by antibody and $C^{\prime}$. Figure 5 illustrates that even when

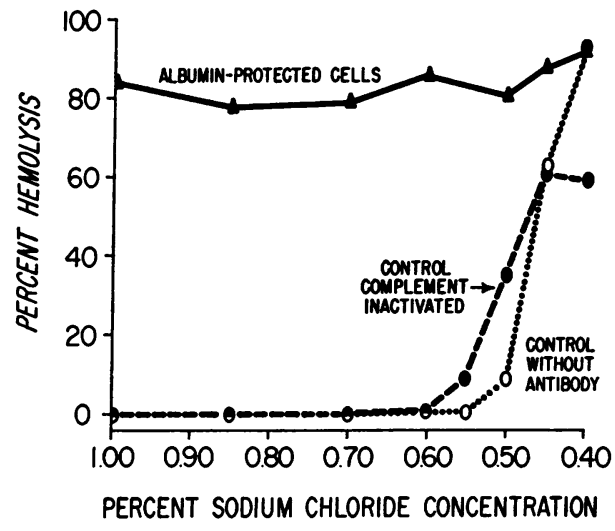

Fig. 2. Rabbit antihuman Red CELl antiserum : osMOTIC FRAGILITY OF ALBUMIN-PROTECTED AND CONTROL Cells after incubation. See Figure 1 for the components of each incubation mixture and their proportions; albumin was added in $2.6 \mathrm{mM}$ concentration.

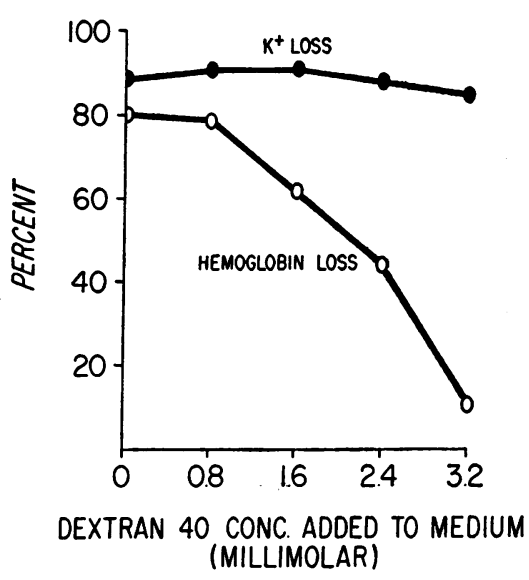

Fig. 3. The EFFECT OF DEXTRAN 40 on LOSS OF POTASSIUM AND HEMOGLOBIN PRODUCED BY RABBIT ANTIHUMAN RED CELl ANTISERUM AND $C^{\prime}$. Each sample contained $0.2 \mathrm{ml}$ red cells, $1.6 \mathrm{ml}$ fresh serum, $2.4 \mathrm{ml}$ Tris$\mathrm{NaCl}$ buffer, and $0.12 \mathrm{ml}$ antiserum.

present in concentrations twice the fully protective concentrations of Dextran 40, Dextran 10 still fails to offer protection against hemoglobin loss. Sucrose similarly failed to protect against hemolysis. Consequently, both Dextran 10 and sucrose may be presumed to have smaller molecular dimensions than the defect in the membrane produced by antibody and $C^{\prime}$. Dextran 20, however, had an effect intermediate between that of Dextran 10 and Dextran 40 , as illustrated in Figure 5. Concentrations of Dextran 20 higher than $4.5 \mathrm{mM}$ appeared to decrease $\mathrm{C}^{\prime}$ activity as evidenced by a decrease in loss of potassium, and therefore it was not possible to study concentrations of Dextran 20 that would protect completely against hemolysis. The concentration of Dextran 20 that decreased hemoglobin loss to $50 \%$ of the nonprotected control value was, however, approximately double the concentration of Dextran 40 that afforded similar protection. This suggests that approximately $50 \%$ of the Dextran 20 molecules are protective and $50 \%$ nonprotective, presumably because the latter are smaller than the size of the defects in the cell membrane.

To test this interpretation, the protective effect of a 1:1 mixture of Dextran 40 and Dextran 10 was compared with that of Dextran 20 and is illustrated also in Figure 5. That the molar concentrations of this Dextran 40-10 mixture that were protective were nearly identical with the 


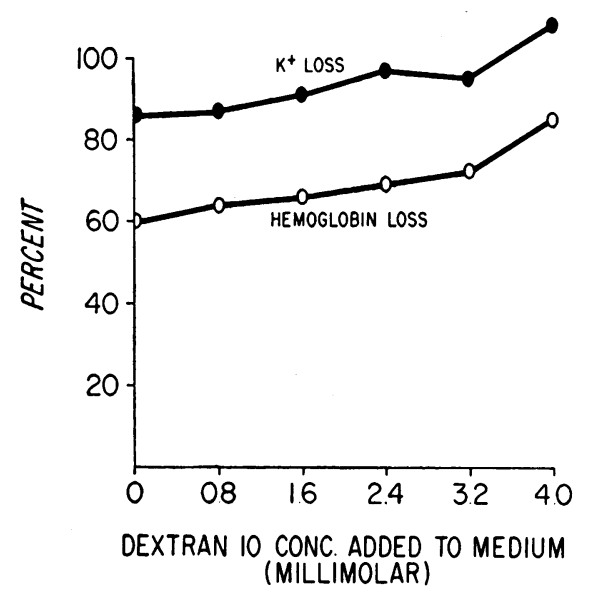

Fig. 4. The EFFECT OF DEXTRAN 10 on LOSS OF POTASSIUM AND HEMOGLOBIN PRODUCED BY RABBIT ANTIHUMAN RED CELl ANTISERUM AND $C^{\prime}$. Each sample contained $0.2 \mathrm{ml}$ red cells, $1.6 \mathrm{ml}$ fresh serum, $2.4 \mathrm{ml}$ Tris$\mathrm{NaCl}$ buffer, and $0.11 \mathrm{ml}$ antiserum.

protective concentrations of Dextran 20 supports the impression that the Dextran 20 curve can be accounted for by the behavior of the $50 \%$ of the Dextran 20 molecules that are protective, whereas by analogy to the Dextran 40-10 curve, the permeating Dextran 20 molecules would not be expected to alter the protective effort of the nonpermeating molecules. Information about the molecular size distribution curve of these dextrans, based on light scattering $(\mathrm{Mw}),{ }^{9}$ indicates that approximately $98 \%$ of Dextran 10 , which is smaller than the membrane defect, is composed of molecules less than 20,000 in molecular weight. Ninety per cent of Dextran 40 , which is larger than the defect, is greater than 20,000 in molecular weight, and the median molecular weight of Dextran 20 is 20,000 . Thus, the membrane defect has approximately the same dimensions as dextran having a molecular weight $(\mathrm{Mw})$ of 20 ,000 as measured by light scattering.

Studies of the rabbit antihuman red cell antiserum carried out with types $\mathrm{O}, \mathrm{AB}, \mathrm{A}$, and $\mathrm{B}$ cells all reveal a similar pattern of protection by Dextran 20, Dextran 40, and albumin against hemolysis but no protection against loss of potassium.

These studies with rabbit antihuman red cell serum indicate that its action, with $\mathrm{C}^{\prime}$, on the

\footnotetext{
${ }^{9}$ Kindly provided by Dr. Edward F. Grassl of Pharmacia Fine Chemicals, Inc., New York, N. Y.
}

cell membrane produces defects with smaller effective radius than hemoglobin, albumin, Dextran 40 , and $50 \%$ of Dextran 20 molecules and larger than Dextran 10, $50 \%$ of Dextran 20, or sucrose molecules; thus, red cell swelling must take place before actual hemolysis occurs. Hemolysis by this antibody and $\mathrm{C}^{\prime}$ proceeds by a colloid-osmotic mechanism. These results agree with those of Green and associates (13) in their studies of the effects of rabbit hemolysin on mouse erythrocytes. Confirmation of the colloid-osmotic hemolytic effect of this antibody was obtained by evaluation of the prehemolytic volume of unhemolyzed cells separated from hemolyzed cells after an unprotected incubation in which there was $57 \%$ hemolysis. Although counting of the agglutinated cells was not possible, estimation of the mean cell volume (MCV) was made by calculation of the mean corpuscular hemoglobin concentrations $(\mathrm{MCHC})$ before and after incubation. Final $\mathrm{MCV}=$ original cell volume $\times[\mathrm{MCHC}$ (original) $/ \mathrm{MCHC}$ (final)]. After a 90-minute incubation the control cells with $\mathrm{C}^{\prime}$ inactivated were found to have a volume of $85 \mu^{3}$, and the damaged but unhemolyzed cells had a volume of $114 \mu^{3}$.

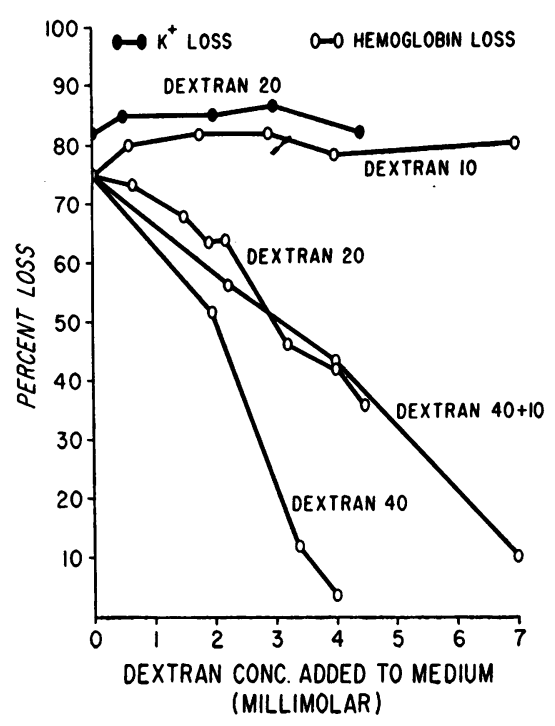

Fig. 5. Comparison of the PROtective efFects of DEXTRAn 20 With DeXtrans 40 and 10 . Each sample contained $0.1 \mathrm{ml}$ red cells, $0.8 \mathrm{ml}$ fresh serum, $1.2 \mathrm{ml}$ Tris$\mathrm{NaCl}$ buffer. Only the loss of potassium in the Dextran 20 experiments is represented. The concentrations labeled Dextran $40+10$ represent the total molarity contributed by a $1: 1$ mixture of the two dextrans. 
Studies utilizing human anti- $A$. The previous experiments were repeated to compare the effects of human anti-A and $C^{\prime}$ on group $A_{1}$ human red cells with those obtained with rabbit antihuman red cell serum. Figure 6 shows the results of such a study. Albumin failed to provide the complete protection against hemolysis observed in the experiments with rabbit antihuman red cell antibody.

Since the bovine serum albumin molecule is larger than human hemoglobin, we concluded that the action of human anti- $\mathrm{A}$ and $\mathrm{C}^{\prime}$ produced red cell membrane defects large enough to permit the direct escape of hemoglobin without the necessity of prior cell swelling. To support this conclusion, an experiment was designed in which human hemoglobin was added to the extracellular medium. It was not technically possible to achieve as concentrated solutions of hemoglobin in the medium as had been utilized with albumin. Nevertheless, Figure 7 illustrates that at molar concentrations of extracellular hemoglobin analogous to concentrations of albumin (Figure 1), which were significantly protective against antihuman red cell serum, hemoglobin failed to inhibit hemolysis. We concluded that human anti-A antiserum, in contrast to rabbit antihuman red cell antiserum, produced membrane defects of sufficient size to permit hemoglobin escape from the cell directly without prior cell swelling. The results agree with and extend the observation of Jacob and Jandl (28) that addition of sucrose to

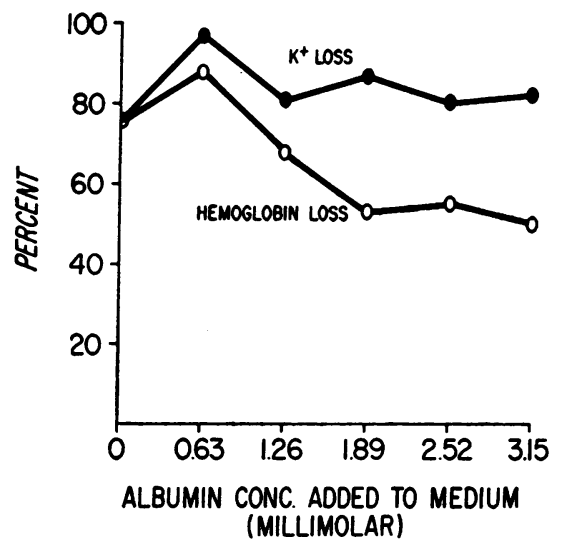

Fig. 6. The effect of albumin on loss of potasSIUM AND HEMOGLOBIN PRODUCED BY HUMAN ANTI-A AND $C^{\prime}$. Each sample contained $0.1 \mathrm{ml}$ red cells, $2.0 \mathrm{ml}$ fresh serum, and $0.3 \mathrm{ml}$ antiserum.

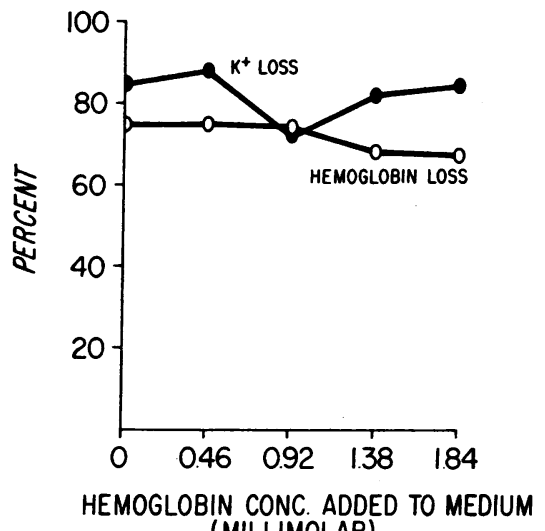

(MILLIMOLAR)

Fig. 7. THE EFFECT OF HEMOGLOBIN ON LOSS OF POTASSIUM AND HEMOGLOBIN PRODUCED BY HUMAN ANTI-A AND $C^{\prime}$. Each sample contained $0.1 \mathrm{ml}$ red cells, $2.0 \mathrm{ml}$ fresh serum, $2.0 \mathrm{ml}$ hemoglobin solution, and $0.3 \mathrm{ml}$ antiserum.

the medium did not prevent hemolysis by human anti-A and $\mathrm{C}^{\prime}$.

Studies utilizing fractionated antisera. Goodman (29) and Johnson, Woernley, and Pressman (30) have found that the rabbit produces $7 \mathrm{~S} \gamma_{2}$ hemolysin when immunized repeatedly with human red cells. Hemolytic activity in human anti-A sera has been found in both $7 \mathrm{~S}$ and $19 \mathrm{~S}$ fractions by McDuffie, Kabat, Allen, and Williams (31). The $7 \mathrm{~S}$ fraction of the rabbit antihuman red cell serum was incubated with human group $A_{1}$ red cells with and without added albumin; the results of this experiment are shown in Table I. Loss of hemoglobin produced by the $7 \mathrm{~S}$ fraction of the rabbit antihuman red cell antibody was markedly inhibited by albumin, whereas loss of potassium was unaffected. These results are identical to those observed with the unfractionated antiserum. The total loss of hemoglobin and potassium produced by the amount of the $7 \mathrm{~S}$ fraction of human anti-A employed in these experiments did not exceed 28\%; there was still no significant inhibition of loss of hemoglobin relative to loss of potassium in albumin protected tests. These results are comparable to those obtained with the unfractionated anti-A serum. In summary, the $7 \mathrm{~S}$ antibody fractions containing the hemolytic activity of these antisera behaved like the respective whole native sera in terms of the size of the defects induced in the red cell membrane. The size of the membrane 
TABLE I

The $7 S$ fractions of rabbit antihuman red cell antiserum and human anti- $A$ : the effect of albumin on loss of potassium and hemoglobin

\begin{tabular}{cccc}
\hline & $\begin{array}{c}\text { Albumin } \\
\text { concen- } \\
\text { tration } \\
\text { added to } \\
\text { medium }\end{array}$ & $\begin{array}{c}\text { Potas- } \\
\text { sium } \\
\text { loss }\end{array}$ & $\begin{array}{c}\text { Hemo- } \\
\text { globin } \\
\text { loss }\end{array}$ \\
\hline Antiserum & $m M$ & $\%$ & $\%$ \\
Rabbit & 0 & 68 & 58 \\
$\begin{array}{c}\text { antihuman } \\
\text { red cell }\end{array}$ & 3.2 & 77 & 12 \\
$\begin{array}{c}\text { Human } \\
\text { anti-A } \dagger\end{array}$ & 0 & 28 & 26 \\
& 3.2 & 22 & 13
\end{tabular}

* Each sample contained $0.2 \mathrm{ml}$ red cells, $1.6 \mathrm{ml}$ serum, and $0.2 \mathrm{ml}$ antiserum fraction.

$\dagger$ Each sample contained $0.1 \mathrm{ml}$ red cells, $2.0 \mathrm{ml}$ serum, and $0.3 \mathrm{ml}$ antiserum fraction.

defect is not apparently related primarily to the molecular species of antibody involved, in that two $7 \mathrm{~S}$ antibodies of comparable molecular size, but of different origin and specificity, produced membrane defects of different sizes.

Studies utilizing rabbit antihuman $A$. When antihuman $\mathrm{A}$ of rabbit origin was incubated with human group $\mathrm{A}_{1}$ red cells and $\mathrm{C}^{\prime}$, albumin added to the medium did not significantly inhibit cellular loss of either potassium or hemoglobin (Table II). Thus, rabbit antihuman A produced membrane defects of greater size than the hemoglobin molecule. Its action in this respect was similar to human anti-A and different from rabbit antihuman red cell serum. The difference in results between the two antisera of rabbit origin, but of different specificity, indicates that the size of the membrane defect created by antibody and $\mathrm{C}^{\prime}$ does not appear to be a characteristic of the animal species in which the antibody is produced.

TABLE II

Rabbit anti-A: the effects of albumin on loss of potassium and hemoglobin*

\begin{tabular}{ccc}
\hline \hline $\begin{array}{c}\text { Albumin } \\
\text { concen- } \\
\text { tration } \\
\text { added to } \\
\text { medium }\end{array}$ & $\begin{array}{c}\text { Potas- } \\
\text { sium } \\
\text { loss }\end{array}$ & $\begin{array}{c}\text { Hemo- } \\
\text { globin } \\
\text { loss }\end{array}$ \\
\hline$m M$ & $\%$ & $\%$ \\
0 & 60 & 47 \\
1.6 & 63 & 36 \\
3.2 & 66 & 34 \\
\hline
\end{tabular}

* Each sample contained $0.2 \mathrm{ml}$ red cells, $3.0 \mathrm{ml}$ serum, and $0.4 \mathrm{ml}$ antiserum.
Rather, the characteristic size of the membrane defect appears to be related to the antigen against which the antibody is directed, i.e., the immunological specificity of the antigen-antibody reaction.

\section{Discussion}

In these experiments, size of the antibody- $\mathrm{C}^{\prime}-$ induced membrane defects can be defined in terms of the size in solution of molecules which do or do not protect the cells against colloid osmotic lysis. A variety of methods have been used to assess the size and dimensions of macromolecules, and results have varied widely depending on techniques employed and the physical state of the molecules under the conditions of the test, as has been discussed by Edsall (32). Based on X-ray studies of human albumin, Low (33) has suggested that the molecule has an elongated shape.

TABLE III

Stokes-Einstein equation and values of effective diffusion radius for various substances

\begin{tabular}{|c|c|c|c|}
\hline \multirow[b]{2}{*}{ Molecule } & \multicolumn{2}{|c|}{$\mathrm{RES}_{\mathrm{ES}}=\frac{\mathrm{RT}}{6 \pi \eta \mathrm{DN}^{*}}$} & \multirow[b]{2}{*}{ References } \\
\hline & Mol wt & RES in $\AA$ & \\
\hline Sucrose & 342 & 4.4 & 40,41 \\
\hline Dextran & 6,000 & 16.8 & 43 \\
\hline Dextran & 16,000 & 28.3 & 43 \\
\hline Dextran & 18,000 & 30.1 & 43 \\
\hline Dextran & 20,000 & 32.0 & 43 \\
\hline Hemoglobin & 68,000 & 32.5 & 44 \\
\hline Albumin & 69,000 & 35.5 & 43,44 \\
\hline
\end{tabular}

$\mathrm{R}_{\mathrm{ES}}=$ effective diffusion radius, $\mathrm{R}=$ gas constant, $\mathrm{T}=$ temperature, $\eta=$ viscosity of water, $\mathrm{D}=$ diffusion coefficient, and $\mathrm{N}=$ Avogadro's number.

A spherical model fits data obtained on bovine albumin solutions by Loeb and Scheraga (34). Similarly, dextrans have been described as a long slender molecule by Grönwall (35) and by Ingelman and Halling (36); Ogston and Woods $(37,38)$ have suggested that more symmetrical models fit the data better. Hemoglobin, even in the unhydrated state, has been described as a fairly symmetrical molecule by Perutz (39).

To describe the diffusion behavior of large molecules in solution through porous membranes, the effective diffusion radius, calculated from the Stokes-Einstein equation (Table III), has been demonstrated by Pappenheimer (40), Pappenheimer, Renkin, and Borrero (41), and Ren- 
kin (42) to provide a useful and valid estimate of molecular size. The effective diffusion radius, simply stated, is the radius of a sphere with equivalent diffusion coefficient. Values of effective diffusion radii for the substances used in these experiments were taken from the literature and are listed in Table III.

By relating these estimates of molecular size to the present experimental results, the size of the antibody- $\mathrm{C}^{\prime}$ induced membrane defects can be defined more specifically. The holes created by the rabbit antihuman red cell serum and human $\mathrm{C}^{\prime}$ are approximately equal to the median molecular size of Dextran 20, molecular weight 20,000, or $32 \AA$ in effective radius. On the other hand, the holes produced by antihuman $\mathrm{A}$ of either human or rabbit origin and human $\mathrm{C}^{\prime}$ must be greater than $32.5 \AA$ in effective radius. These estimates depend, of course, on the validity of the estimates of molecular size employed and the assumption that there are no significant interactions between the test molecules and the membrane "holes." They do, however, provide estimates of the relative size, in a functional sense, of the membrane lesions induced by these different antibodies and human $\mathrm{C}^{\prime}$.

In his original description of colloid-osmotic hemolysis, Wilbrandt considered lysis of sensitized sheep cells by $\mathrm{C}^{\prime}$ to be nonosmotic on the basis of the shape of osmotic fragility curves (9). However, as Ponder (45) has pointed out, the critical volume for osmotic lysis in a variety of hemolytic systems is very little in excess of the initial volume. Different critical hemolytic volumes have been observed in the course of erythrocyte lysis by different agents, and the colloidosmotic theory does not elucidate the nature of this effect of lysins. Jacob and Jandl (28) have presented evidence that sucrose inhibits hemolysis caused by sulfhydryl inhibitors and that in this case lysis occurs by a colloid osmotic mechanism. These authors found that addition of sucrose to the medium did not prevent hemolysis of group A human red cells by human anti-A and $\mathrm{C}^{\prime}$ and suggested that relatively large membrane defects were produced, a finding consistent with our results.

The maintenance of normal intracellular potassium levels in the erythrocyte depends upon the balance between normal potassium leakage from the cells in the direction of the electrochemical gradient and active transport of potassium into cells against this gradient by energy-requiring processes. The question might be raised whether the red cell potassium loss we observed could simply be the result of inactivation of the "potassium pump" allowing the normal potassium leak to proceed unopposed, as, for example, Eckel (46) has shown in red cells incubated with small concentrations of sodium fluoride. This question is answered by consideration of the normal rate of potassium leakage from red cells determined by Sheppard and Martin (47) and Ponder (48, 49), which is far too slow to produce potassium losses of the magnitude observed after 2-hour incubations in the present studies.

The structural counterpart of the cell membrane of these physiologically demonstrated defects induced by antibody and $\mathrm{C}^{\prime}$ is not known. They are much larger than the normal pores of the human red cell membrane, estimated by Solomon (50) to have a radius of about $3.5 \AA$. The defects in the membrane, at least in the case of the more precisely defined lesion induced by the rabbit antihuman red cell serum, is of the same general order of size as the molecular cross sectional area calculated for rabbit antibodies against sheep cells by Heidelberger, Weil, and Treffers (51). Latta (52), studying antibody-lysed sheep erythrocytes with the electron microscope, described surface "cracks" in the affected cells. Goldberg and Green (11) have observed focal pouching and folding of the cell membrane with the electron microscope in ascites tumor cells treated with antibody and $\mathrm{C}^{\prime}$.

Complement alone does not appear to determine the size of the induced red cell membrane defects. Human $\mathrm{C}^{\prime}$ was utilized in all of our experiments, and yet the size of the membrane defects varied with different antisera. The hypothesis may be proposed that the antigenic sites may have been critical in determining the size of the defect created by antibody and $C^{\prime}$. All of the specific antigen(s) recognized by the antibody in the rabbit antihuman red cell serum used in these experiments is not known. Clearly, however, the antibodies were not directly primarily against antigens of the human $\mathrm{ABO}$ system. The rabbits were immunized with human group $\mathrm{O}$ red cells, and the antiserum, when tested against 
the erythrocytes of all the human $\mathrm{ABO}$ groups, produced similar membrane defects that were smaller than those induced by anti-A sera.

Little is known of the distribution of antigen sites or functionally active sites on the surface of the red cell membrane. The technique employed in these experiments may provide an approach by which to evaluate whether the size of the erythrocyte membrane defect has a relationship to any structural characteristic of the involved antigens.

\section{Summary}

1. Rabbit antihuman red cell serum and human complement $\left(\mathrm{C}^{\prime}\right)$ produce functional holes in human erythrocyte membranes that are $32 \AA$ in effective radius. Destruction of these injured cells in vitro ensues by colloid-osmotic lysis.

2. In contrast, antihuman $A$ of rabbit and human origin with human complement produces holes greater than $32.5 \AA$ in radius, permitting direct escape of hemoglobin.

3 . The size of the membrane defect is not related either to molecular size of the antibody molecules or to the species of animal producing the antibody.

4. We suggest that specificity of the antigenic sites involved determines the size of the membrane defect produced. In turn, the mechanism of the complement-dependent hemolysis is determined by the size of the induced membrane defects.

\section{References}

1. Swisher, S. N., and L. E. Young. Studies of the mechanisms of erythrocyte destruction initiated by antibodies. Trans. Ass. Amer. Phycns 1954, 67, 124.

2. Cutbush, M., and P. L. Mollison. Relation between characteristics of blood-group antibodies in vitro and associated patterns of red-cell destruction in vivo. Brit. J. Haemat. 1958, 4, 115.

3. Jandl, J. H., A. Richardson-Jones, and W. B. Castle. The destruction of red cells by antibodies in man. I. Observations on the sequestration and lysis of red cells altered by immune mechanisms. J. clin. Invest. 1957, 36, 1428.

4. Jandl, J. H., and M. E. Kaplan. The destruction of red cells by antibodies in man. III. Quantitative factors influencing the patterns of hemolysis in vivo. J. clin. Invest. 1960, 39, 1145.

5. Mayer, M. M. Complement and complement fixation in Experimental Immunochemistry, 2nd ed., E. A.
Kabat, Ed. Springfield, Ill., Charles C Thomas, 1961, p. 133.

6. Ponder, E. Hemolysis and Related Phenomena. New York, Grune \& Stratton, 1948, p. 168.

7. Williams, T. F., C. C. Fordham III, W. Hollander, Jr., and L. G. Welt. A study of the osmotic behavior of the human erythrocyte. J. clin. Invest. 1959, 38, 1587.

8. Davson, H. Studies on the permeability of erythrocytes. III. The cation content of erythrocytes of rabbit's blood in hyper- and hypo-tonic sera. Biochem. J. 1936, 30, 391.

9. Wilbrandt, W. Osmotische Natur sogenannter nichtosmotischer Hämolysen (Kolloidosmotische Hämolyse). Pflügers Arch. ges. Physiol. 1941, 245, 22.

10. Dick, D. A. T. Osmotic properties of living cells. Int. Rev. Cytol. 1959, 7, 387.

11. Goldberg, B., and H. Green. The cytotoxic action of immune gamma globulin and complement on Krebs ascites tumor cells. I. Ultrastructural studies. J. exp. Med. 1959, 109, 505.

12. Green, H., R. A. Fleischer, P. Barrow, and B. Goldberg. The cytotoxic action of immune gamma globulin and complement on Krebs ascites tumor cells. II. Chemical studies. J. exp. Med. 1959, 109, 511.

13. Green, H., P. Barrow, and B. Goldberg. Effect of antibody and complement on permeability control in ascites tumor cells and erythrocytes. J. exp. Med. 1959, 110, 699.

14. Green, H., and B. Goldberg. The action of antibody and complement on mammalian cells. Ann. N. Y. Acad. Sci. 1960, 87, 352.

15. Ervin, D. M., and L. E. Young. Dangerous universal donors. I. Observations on destruction of recipient's A cells after transfusion of group $O$ blood containing high titer of $\mathrm{A}$ antibodies of immune type not easily neutralizable by soluble A substance. Blood 1950, 5, 61.

16. Baer, H., and U. Rasmussen. Immunization of rabbits with purified blood group A and B substances. J. Immunol. 1960, 85, 1.

17. Kochwa, S., R. E. Rosenfield, L. Tallal, and L. R. Wasserman. Isoagglutinins associated with $\mathrm{ABO}$ erythroblastosis. J. clin. Invest. 1961, 40, 874.

18. Billmeyer, F. W., Jr. Textbook of Polymer Chemistry. New York, Interscience Publishers, 1957, p. 106.

19. Crosby, W. H., J. I. Munn, and F. W. Furth. Standardizing a method for clinical hemoglobinometry. U. S. armed Forces med. J. 1954, 5, 693.

20. Ponder, E. On properties of the red cell ghost. J. exp. Biol. 1942, 18, 257.

21. Passow, H., and K. Tillman. Untersuchungen über den Kaliumverlust bleivergifteter Menschenerythrocyten. Pflügers Arch. ges. Physiol. 1955, 262, 23.

22. Parpart, A. K., P. B. Lorenz, E. R. Parpart, J. R. Gregg, and A. M. Chase. The osmotic resistance 
(fragility) of human red cells. J. clin. Invest. 1947, 26, 636.

23. Toribara, T. V. Centrifuge type of ultrafiltration apparatus. Analyt. Chem. 1953, 25, 1286.

24. Scatchard, G., A. C. Batchelder, and A. Brown. Chemical, clinical, and immunological studies on the products of human plasma fractionation. VI. The osmotic pressure of plasma and of serum albumin. J. clin. Invest. 1944, 23, 458.

25. Adair, G. S. A theory of partial osmotic pressures and membrane equilibria, with special reference to the application of Dalton's law to haemoglobin solutions in the presence of salts. Proc. roy. Soc. A 1928, 120, 573.

26. Rowe, D. S. Colloid osmotic pressures of dextran, serum, and dextran-serum mixtures. Nature (Lond.) 1955, 175, 554.

27. Grönwall, A., and B. Ingelman. Untersuchungen über Dextran and sein Verhalten bei parenteraler Zufuhr. II. Acta physiol. scand. 1945, 9, 1.

28. Jacob, H. S., and J. H. Jandl. Effects of sulfhydryl inhibition on red blood cells. I. Mechanism of hemolysis. J. clin. Invest. 1962, 41, 779.

29. Goodman, H. S. Relationship of serological reactivity to antibody molecular weight. Nature (Lond.) 1958, 182, 1100.

30. Johnson, A., D. Woernley, and D. Pressman. Sedimentation properties of human and sheep erythrocyte hemolysins. J. Immunol. 1957, 79, 234.

31. McDuffie, F. C., E. A. Kabat, P. Z. Allen, and C. A. Williams, Jr. An immunochemical study of the relationship of human blood group isoantibodies to $\boldsymbol{\gamma}_{1}$ - and $\boldsymbol{\gamma}_{\mathbf{2}}$-globulins. J. Immunol. 1958, 81, 48 .

32. Edsall, J. T. The size, shape and hydration of protein molecules in The Proteins, $H$. Neurath and K. Bailey, Eds. New York, Academic Press, 1953, vol. 1, part B, p. 549.

33. Low, B. W. Preparation and properties of serum and plasma proteins. XXXIV. An X-ray study of crystalline human serum albumin preparations. J. Amer. chem. Soc. 1952, 74, 4830.

34. Loeb, G. I., and H. A. Scheraga. Hydrodynamic and thermodynamic properties of bovine serum albumin at low pH. J. phys. Chem. 1956, 60, 1633.

35. Grönwall, A. Dextran and Its Use in Colloidal Infusion Solutions. New York, Academic Press, 1957, p. 47.

36. Ingelman, B., and M. S. Halling. Some physicochemical experiments on fractions of dextran. Arkiv. Kemi 1949, 1, 61.

37. Ogston, A. G., and E. F. Woods. Molecular configuration of dextrans in aqueous solution. $\mathrm{Na}$ ture (Lond.) 1953, 171, 221.
38. Ogston, A. G., and E. F. Woods. The sedimentation of some fractions of degraded dextran. Trans. Faraday Soc. 1954, 50, 635.

39. Perutz, M. D. X-ray analysis of haemoglobin in Symposium on Protein Structure, A. Neuberger, Ed. New York, John Wiley and Sons, 1957, p. 136.

40. Pappenheimer, J. R. Passage of molecules through capillary walls. Physiol. Rev. 1953, 33, 387.

41. Pappenheimer, J. R., E. M. Renkin, and L. M. Borrero. Filtration, diffusion and molecular sieving through peripheral capillary membranes. Amer. J. Physiol. 1951, 167, 13.

42. Renkin, E. M. Filtration, diffusion, and molecular sieving through porous cellulose membranes. J. gen. Physiol. 1954, 38, 225.

43. Grotte, G. Passage of dextran molecules across the blood-lymph barrier. Acta chir. scand. 1956, suppl. 211.

44. Pappenheimer, J. R. Uber die Permeabilität der Glomerulummembranen in der Niere. Klin. Wschr. 1955, 33, 362.

45. Ponder, E. Red cell structure and its breakdown in Protoplasmatologia, Handbuch der Protoplasmaforschung, L. V. Heilbrunn and F. Weber, Eds. Vienna, Springer, 1955, vol. 10, p. 2.

46. Eckel, R. E. Potassium exchange in human erythrocytes. I. General aspects of the fluoride effect. J. cell. comp. Physiol. 1958, 51, 81.

47. Sheppard, C. W., and W. R. Martin. Cation exchange between cells and plasma of mammalian blood. I. Methods and application to potassium exchange in human blood. J. gen. Physiol. 1950, 33, 703.

48. Ponder, E. The rate of loss of potassium from human red cells in systems to which lysins have not been added. J. gen. Physiol. 1948, 32, 461.

49. Ponder, E. Anomalous features of the loss of $\mathrm{K}^{+}$ from human red cells : results of extended observations. J. gen. Physiol. 1951, 34, 359.

50. Solomon, A. K. The permeability of red cells to water and ions. Ann. N. Y. Acad. Sci. 1958, 75, 175.

51. Heidelberger, M., A. J. Weil, and H. P. Treffers. Quantitative chemical studies on complement or alexin. II. The interrelation of complement with antigen-antibody compounds and with sensitized red cells. J. exp. Med. 1941, 73, 695

52. Latta, $H$. The surface of the mammalian erythrocyte. An electron microscope study of the effect of lipid solvents, fixatives, hypotonicity, and hemolysin (Amboceptor) and complement. Blood 1952, 7, 508. 